\title{
Marinomonas arctica sp. nov., a psychrotolerant bacterium isolated from the Arctic
}

Correspondence

Yong Yu

yuyong@pric.gov.cn

\author{
De-Chao Zhang, ${ }^{1,2}$ Hui-Rong Li, ${ }^{1}$ Yu-Hua Xin, ${ }^{3}$ Hong-Can Liu, ${ }^{3}$ Bo Chen, ${ }^{1}$ \\ Zhen-Ming $\mathrm{Chi}^{2}{ }^{2}$ Pei-Jin $\mathrm{Zhou}^{3}$ and Yong $\mathrm{Yu}^{1}$
}

${ }^{1}$ SOA Key Laboratory for Polar Science, Polar Research Institute of China, Shanghai 200136, PR China

${ }^{2}$ UNESCO Chinese Center of Marine Biotechnology, Ocean University of China, Qingdao 266003, PR China

${ }^{3}$ China General Microbiological Culture Collection Center and State Key Laboratory of Microbial Resources, Institute of Microbiology, Chinese Academy of Sciences, Beijing 100101, PR China

\begin{abstract}
A novel psychrotolerant, Gram-negative, motile bacterium, designated strain $328^{\top}$, was isolated from sea-ice samples collected off the Canadian Basin of the Arctic Ocean $\left(78^{\circ} 23^{\prime} 14^{\prime \prime} \mathrm{N}\right.$ $\left.149^{\circ} 06^{\prime} 55^{\prime \prime} \mathrm{W}\right)$. Strain $328^{\top}$ was able to grow at $0-37^{\circ} \mathrm{C}$, with optimum growth at $25-27^{\circ} \mathrm{C}$. It possessed phosphatidylethanolamine and phosphatidylglycerol as major phospholipids and $\mathrm{C}_{10: 0} 3-\mathrm{OH}(31.78 \%), \mathrm{C}_{18: 1} \omega 7 c(27.50 \%)$ and iso- $\mathrm{C}_{15: 0} 2-\mathrm{OH}$ and/or $\mathrm{C}_{16: 1} \omega 7 c(19.22 \%)$ as predominant cellular fatty acids. The DNA G+C content of strain $328^{\top}$ was $45.2 \mathrm{~mol} \%$. Phylogenetic analysis based on 16S rRNA gene sequences indicated that strain $328^{\top}$ was a member of the genus Marinomonas (92.7-96.0\% 16S rRNA gene sequence similarity). On the basis of phenotypic, chemotaxonomic and phylogenetic distinctiveness, strain $328^{\top}$ was considered to represent a novel species of the genus Marinomonas. The name Marinomonas arctica sp. nov. is proposed, with strain $328^{\top}\left(=\right.$ CGMCC $\left.1.6498^{\top}=J C M 14976^{\top}\right)$ as the type strain.
\end{abstract}

The genus Marinomonas was proposed by the reclassification of two species of the genus Alteromonas (Baumann et al., 1972), namely Alteromonas vaga and Alteromonas communis, as Marinomonas vaga and Marinomonas communis, based on 16S rRNA gene sequences (Van Landschoot \& De Ley, 1983). So far, the genus Marinomonas comprises ten species: $M$. communis, $M$. vaga, $M$. mediterranea, $M$. primoryensis, $M$. pontica, $M$. ushuaiensis, M. aquimarina, M. dokdonensis, M. polaris and M. ostreistagni (Baumann et al., 1972; Solano \& SanchezAmat, 1999; Romanenko et al., 2003; Ivanova et al., 2005; Prabagaran et al., 2005; Macián et al., 2005; Yoon et al., 2005; Gupta et al., 2006; Lau et al., 2006). During screening of cold-adapted bacteria from sea-ice samples of the Arctic Ocean, a novel psychrotolerant strain, designated strain $328^{\mathrm{T}}$, was isolated. Based on a polyphasic taxonomic approach, strain $328^{\mathrm{T}}$ was identified as a representative of a novel species of the genus Marinomonas.

Abbreviation: ECL, equivalent chain-length.

The GenBank/EMBL/DDBJ accession number for the 16S rRNA gene sequence of Marinomonas arctica $328^{\top}$ is DQ492749.

A supplementary table showing the fatty acid profiles of strain $328^{\top}$ and other Marinomonas species is available with the online version of this paper.
Strain $328^{\mathrm{T}}$ was isolated from sea-ice samples collected from the Canadian Basin ( $\left.78^{\circ} 23^{\prime} 14^{\prime \prime} \mathrm{N} 149^{\circ} 06^{\prime} 55^{\prime \prime} \mathrm{W}\right)$ using a MARK II ice auger during the Second Chinese National Arctic Research Expedition cruise of the USCGC icebreaker Xue Long into the Canadian Basin in August 2003. Sea-ice samples were cut carefully into $10-20 \mathrm{~cm}$ sections using a sterile saw and placed in sterile plastic bottle to be melted at $4{ }^{\circ} \mathrm{C}$. Strain $328^{\mathrm{T}}$ was obtained using previously described media and methods (Zhang et al., 2006). The novel isolate was routinely grown on marine agar (MA) for 2 days at $25{ }^{\circ} \mathrm{C}$ and maintained as a glycerol suspension $(20 \%, \mathrm{w} / \mathrm{v})$ at $-80{ }^{\circ} \mathrm{C}$. M. polaris JCM $12522^{\mathrm{T}}$, obtained from the JCM, was routinely grown on MA or in marine 2216 broth $(\mathrm{MB})$ at $22{ }^{\circ} \mathrm{C}$ and used as a reference strain.

DNA was extracted from strain $328^{\mathrm{T}}$ and purified as described by Sambrook et al. (1989). The 16S rRNA gene was amplified by PCR with two universal primers (Zhang et al., 2006). Purified PCR product was ligated to PMD 18-T (TaKaRa Bio) and cloned according to the manufacturer's instructions. Sequencing reactions were carried out using an ABI BigDye 3.1 sequencing kit (Applied BioSystems) and an automated DNA sequencer (model ABI3730; Applied Biosystems). The almost complete 16S rRNA gene sequence (1465 bp) of strain $328^{\mathrm{T}}$ was submitted to 
GenBank and EMBL to search for similar sequences using the BLAST algorithm. A phylogenetic tree was constructed using the Kimura two-parameter and pairwise-deletion model analysis implemented in the MEGA version 3.0 program (Kumar et al., 2004). Stability of clustering of the tree was evaluated by bootstrap analysis of 1000 datasets. Phylogenetic analysis (Fig. 1) showed that strain $328^{\mathrm{T}}$ was grouped with members of the genus Marinomonas. Sequence similarity calculations based on neighbourjoining analysis indicated that the closest relatives of strain $328^{\mathrm{T}}$ were the type strains of M. pontica $(96.0 \%)$, M. polaris $(95.9 \%)$ and M. primoryensis $(95.7 \%)$. Lower sequence similarities $(<97.0 \%)$ were found with all recognized species of the genus Marinomonas. It has been suggested that in bacterial strains with less than $97 \% 16 \mathrm{~S}$ rRNA gene sequence similarity, levels of DNA-DNA hybridization are less than $70 \%$ (Stackebrandt \& Goebel, 1994), which defines a genomic species (Wayne et al., 1987). Thus, based on 16S rRNA gene sequence analysis, strain $328^{\mathrm{T}}$ represents a novel species.

Cell morphology was examined with an Axioplan 2 microscope. Colony morphology was observed on MA after incubation at $25{ }^{\circ} \mathrm{C}$ for $24-36 \mathrm{~h}$. The growth temperature was determined with a TN3F temperature-gradient incubator (Advantec). The $\mathrm{pH}$ range for growth was determined for the culture in $\mathrm{MB}$ at various $\mathrm{pH}$ values adjusted with $\mathrm{HCl}$ or $\mathrm{NaOH}\left(1 \mathrm{~mol} \mathrm{l}^{-1}\right)$. General physiological tests were performed using conventional methods (Dong \& Cai, 2001). Acid production from carbohydrates was determined as described by Leifson (1963). In addition, biochemical properties were assessed using the API kits (API $20 \mathrm{E}$, API $20 \mathrm{NE}$ and API ZYM; bioMérieux) according to the manufacturer's instructions, except that the inoculum was prepared by suspending cells in a $3 \%(\mathrm{w} / \mathrm{v}) \mathrm{NaCl}$ solution. All of the tests were performed in duplicate. Strain $328^{\mathrm{T}}$ demonstrated an ability to utilize a comparatively wide range of carbon compounds as the sole source of carbon and energy compared with those utilized by its phylogenetic relatives. The morphological, cultural, physiological and biochemical characteristics of strain $328^{\mathrm{T}}$ are given in the species description (see below) or are shown in Table 1.

Cellular polar lipids were extracted and analysed on silica gel plates (Kieselgel 60 F; Merck) by TLC (Kates, 1986).
For fatty acid methyl ester analysis, cell mass of strain $328^{\mathrm{T}}$ was harvested from MA plates after incubation at $25{ }^{\circ} \mathrm{C}$ for 3 days. Fatty acid methyl esters were prepared and analysed according to the standard protocol described in the MIDI (Microbial Identification) system (Sasser, 1990). The main phospholipids present included phosphatidylethanolamine and phosphatidylglycerol. The predominant cellular fatty acids of strain $328^{\mathrm{T}}$ were $\mathrm{C}_{10: 0} 3-\mathrm{OH}(31.78 \%), \mathrm{C}_{18: 1} \omega 7 c$ $(27.50 \%)$, iso- $\mathrm{C}_{15: 0} 2-\mathrm{OH}$ and/or $\mathrm{C}_{16: 1} \omega 7 c(19.22 \%)$, an unknown fatty acid with an equivalent chain-length (ECL) of $11.799(7.44 \%), \mathrm{C}_{16: 0}(5.89 \%), \mathrm{C}_{10: 0}(2.99 \%), \mathrm{C}_{12: 0} 3-$ $\mathrm{OH}(1.43 \%)$ and $\mathrm{C}_{18: 0}(1.11 \%)$. The fatty acid profile of the novel strain resembled those determined for the other species of the genus Marinomonas, but differed in terms of relative amounts of unknown fatty acid (ECL 11.799) and $\mathrm{C}_{10: 0}$ 3-OH (Ivanova et al., 2005; Gupta et al., 2006; Lau et al., 2006). The fatty acid profiles of strain $328^{\mathrm{T}}$ and other Marinomonas species are given in Supplementary Table S1, available in IJSEM Online.

The DNA $G+C$ content was determined using a DU800 spectrophotometer (Beckman) with a thermal controller by the thermal denaturation $\left(T_{\mathrm{m}}\right)$ method (Marmur \& Doty, 1962) using Escherichia coli K-12 as the reference. The DNA $\mathrm{G}+\mathrm{C}$ content of strain $328^{\mathrm{T}}$ was $45.2 \mathrm{~mol} \%$. This value is consistent with the $\mathrm{G}+\mathrm{C}$ content of members of the genus Marinomonas, which ranges from about 41 to $50 \mathrm{~mol} \%$.

Strain $328^{\mathrm{T}}$ could be distinguished from other species of the genus Marinomonas by a combination of physiological and biochemical properties (Table 1). Based on these results, it is concluded that strain $328^{\mathrm{T}}$ represents a novel species of the genus Marinomonas, for which the name Marinomonas arctica sp. nov. is proposed.

\section{Description of Marinomonas arctica sp. nov.}

Marinomonas arctica (arc'ti.ca. L. fem. adj. arctica from the Arctic, referring to the site where the type strain was isolated).

Cells are Gram-negative, psychrotolerant, curved rods, $0.3-$ $0.4 \times 1.2-2.6 \mu \mathrm{m}$ in size. Colonies are non-pigmented, convex, circular and smooth with entire edges. Growth occurs at $0-37{ }^{\circ} \mathrm{C}$ and $\mathrm{pH} 5.0-10.0$, with optimum growth at $25-27{ }^{\circ} \mathrm{C}$ and at approximately $\mathrm{pH} 6.0-9.0$. Growth

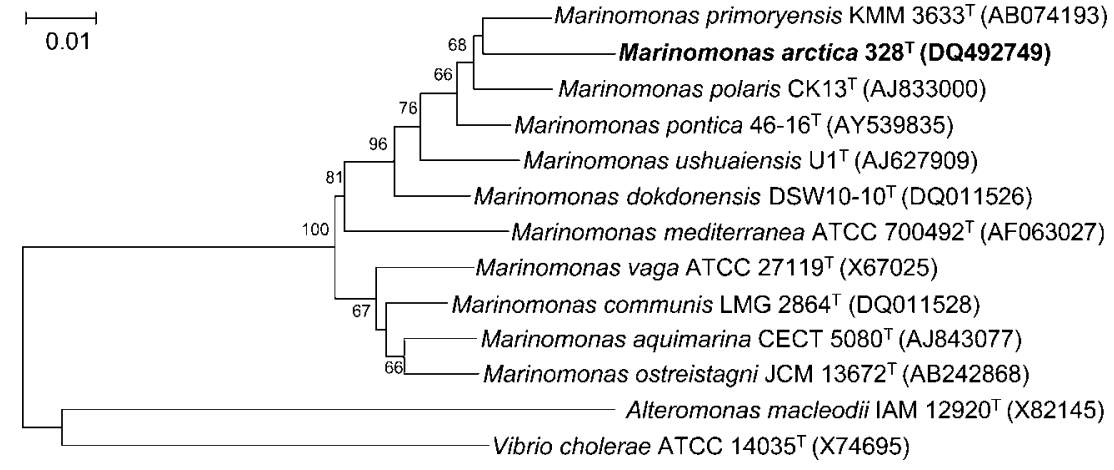

Fig. 1. Phylogenetic dendrogram of Marinomonas arctica sp. nov. and related species based on 16S rRNA gene sequences. The tree was constructed using the neighbour-joining method. Numbers at nodes represent levels of bootstrap support (\%) based on neighbourjoining analysis of 1000 resampled datasets. GenBank accession numbers of $16 \mathrm{~S}$ rRNA gene sequences are given in parentheses. Bar, $1 \%$ sequence divergence. 
Table 1. Phenotypic characteristics that differentiate strain $328^{\top}$ from other Marinomonas species

Strain/species: 1, strain $328^{\mathrm{T}}$; 2, M. pontica (Ivanova et al., 2005; Gupta et al., 2006); 3, M. polaris (Gupta et al., 2006); 4, M. dokdonensis (Yoon et al., 2005); 5, M. ushuaiensis (Prabagaran et al., 2005); 6, M. primoryensis (Romanenko et al., 2003; Gupta et al., 2006); 7, M. communis (Baumann et al., 1972). +, Positive; -, negative; $\mathrm{w}$, weak reaction; ND, not determined.

\begin{tabular}{|c|c|c|c|c|c|c|c|}
\hline Characteristic & 1 & 2 & 3 & 4 & 5 & 6 & 7 \\
\hline \multicolumn{8}{|l|}{ Growth at: } \\
\hline $4{ }^{\circ} \mathrm{C}$ & + & + & + & + & + & + & - \\
\hline $\mathrm{NaCl}$ requirement & - & + & - & + & + & + & + \\
\hline $\mathrm{NaCl}$ tolerance $(\%)$ & 12 & 10 & 11 & 10 & 6 & 6 & 6 \\
\hline Amylase & - & - & - & - & + & - & - \\
\hline Phosphatase & + & + & + & ND & + & + & - \\
\hline \multicolumn{8}{|l|}{ Utilization of: } \\
\hline Cellobiose & + & + & + & + & - & + & - \\
\hline Erythritol & + & - & + & $\mathrm{ND}$ & - & - & - \\
\hline Galactose & + & - & + & - & + & - & $\mathrm{ND}$ \\
\hline Glycerol & + & + & + & $\mathrm{ND}$ & - & + & + \\
\hline Rhamnose & + & + & - & $\mathrm{ND}$ & - & - & $\mathrm{ND}$ \\
\hline Ribose & + & - & + & + & - & + & - \\
\hline Sorbitol & + & - & + & + & - & - & + \\
\hline DNA G $+C$ content $(\mathrm{mol} \%)$ & 45.2 & 46.5 & 41.2 & $45.3-45.7$ & 43.6 & $45.3-45.6$ & $45.9-47.9$ \\
\hline
\end{tabular}

occurs in the presence of $0-12 \%(\mathrm{w} / \mathrm{v}) \mathrm{NaCl}$. Grows aerobically and produces catalase and cytochrome oxidase. Indole production and Voges-Proskauer are negative. Does not reduce nitrate or produce hydrogen sulfide. Arginine dihydrolase, lysine decarboxylase, ornithine decarboxylase, urease, gelatinase, agarase, caseinase, amylase, chitinase, lecithinase, esterase (C4), esterase lipase (C8), lipase (C14), $\alpha$-chymotrypsin, naphthol-AS-BI-phosphohydrolase, cystine arylamidase, valine arylamidase, leucine arylamidase, $\alpha$ galactosidase, $\beta$-glucuronidase and $N$-acetyl- $\beta$-glucosaminidase are negative. Tests for citrate utilization, $\alpha$-glucosidase, trypsin, acid phosphatase and alkaline phosphatase are positive. The following substrates are utilized as sole carbon sources: glucose, mannitol, D-mannose, sucrose, D-sorbitol, D-arabinose, L-rhamnose, maltose, fructose, D-galactose, erythritol, melibiose, glycerol, cellobiose, raffinose, xylose, melezitose, trehalose, L-proline, L-alanine, L-histidine, gluconate, malate and phenylacetic acid. The following substrates are not utilized as sole carbon sources: salicin, sorbinose, arabitol, amygdalin, dulcitol, inulin, L-leucine, capric acid and adipic acid. Acid is produced from glucose, mannitol, Dmannose, sucrose, D-sorbitol, D-arabinose, L-rhamnose, maltose, fructose, D-galactose, erythritol, melibiose, glycerol, cellobiose, raffinose, xylose, melezitose and trehalose. The main phospholipids present include phosphatidylethanolamine and phosphatidylglycerol. The predominant cellular fatty acids of strain $328^{\mathrm{T}}$ are $\mathrm{C}_{10: 0} \quad 3-\mathrm{OH} \quad(31.78 \%)$, $\mathrm{C}_{18: 1} \omega 7 c(27.50 \%)$, iso- $\mathrm{C}_{15: 0} \quad 2-\mathrm{OH}$ and/or $\mathrm{C}_{16: 1} \omega 7 c$
(19.22\%), unknown fatty acid (ECL 11.799; 7.44\%) and $\mathrm{C}_{16: 0}(5.89 \%)$. The DNA $\mathrm{G}+\mathrm{C}$ content of the type strain is $45.2 \mathrm{~mol} \%$.

The type strain is $328^{\mathrm{T}}$ (=CGMCC $1.6498^{\mathrm{T}}=\mathrm{JCM} 14976^{\mathrm{T}}$ ), isolated from the Canadian Basin $\left(78^{\circ} 23^{\prime} 14^{\prime \prime} \mathrm{N}\right.$ $\left.149^{\circ} 06^{\prime} 55^{\prime \prime} \mathrm{W}\right)$ in the Arctic.

\section{Acknowledgements}

This work was supported by the National Basic Research Program of China (2004CB719601), the National Natural Science Foundation of China (30500001) and the National Infrastructure of Natural Resources for Science and Technology Program of China (no. 2005DKA21209).

\section{References}

Baumann, L., Baumann, P., Mandel, M. \& Allen, R. D. (1972). Taxonomy of aerobic marine eubacteria. J Bacteriol 110, 402-429.

Dong, X.-Z. \& Cai, M.-Y. (editors) (2001). Determination of biochemical properties. In Manual for the Systematic Identification of General Bacteria, pp. 370-398. Beijing: Science Press (in Chinese).

Gupta, P., Chaturvedi, P., Pradhan, S., Delille, D. \& Shivaji, S. (2006). Marinomonas polaris sp. nov., a psychrohalotolerant strain isolated from coastal sea water off the subantarctic Kerguelen islands. Int J Syst Evol Microbiol 56, 361-364.

Ivanova, E. P., Onyshchenko, O. M., Christen, R., Lysenko, A. M., Zhukova, N. V., Shevchenko, L. S. \& Kiprianova, E. A. (2005). 
Marinomonas pontica sp. nov., isolated from the Black Sea. Int J Syst Evol Microbiol 55, 275-279.

Kates, M. (1986). Techniques of Lipidology, 2nd edn. Amsterdam: Elsevier.

Kumar, S., Tamura, K. \& Nei, M. (2004). MEGA3: integrated software for molecular evolutionary genetics analysis and sequence alignment. Brief Bioinform 5, 150-163.

Lau, K. W. K., Ren, J., Wai, N. L. M., Lau, S. C. L., Qian, P.-Y., Wong, P.-K. \& Wu, M. (2006). Marinomonas ostreistagni sp. nov., isolated from a pearl-oyster culture pond in Sanya, Hainan Province, China. Int J Syst Evol Microbiol 56, 2271-2275.

Leifson, E. (1963). Determination of carbohydrate metabolism of marine bacteria. J Bacteriol 85, 1183-1184.

Macián, M. C., Arahal, D. R., Garay, E. \& Pujalte, M. J. (2005). Marinomonas aquamarina sp. nov., isolated from oysters and seawater. Syst Appl Microbiol 28, 145-150.

Marmur, J. \& Doty, P. (1962). Determination of the base composition of deoxyribonucleic acid from its thermal denaturation temperature. J Mol Biol 5, 109-118.

Prabagaran, S. R., Suresh, K., Manorama, R., Delille, D. \& Shivaji, S. (2005). Marinomonas ushuaiensis sp. nov., isolated from coastal sea water in Ushuaia, Argentina, sub-Antarctica. Int J Syst Evol Microbiol 55, 309-313.

Romanenko, L. A., Uchino, M., Mikhailov, V. V., Zhukova, N. V. \& Uchimura, T. (2003). Marinomonas primoryensis sp. nov., a novel psychrophile isolated from coastal sea-ice in the Sea of Japan. Int $J$ Syst Evol Microbiol 53, 829-832.
Sambrook, J., Fritsch, E. F. \& Maniatis, T. (1989). Molecular Cloning: a Laboratory Manual, 2nd edn. Cold Spring Harbor, NY: Cold Spring Harbor Laboratory.

Sasser, M. (1990). Identification of bacteria by gas chromatography of cellular fatty acids, MIDI Technical Note 101. Newark, DE: MIDI Inc.

Solano, F. \& Sanchez-Amat, A. (1999). Studies on the phylogenetic relationships of melanogenic marine bacteria: proposal of Marinomonas mediterranea sp. nov. Int J Syst Bacteriol 49, 1241-1246.

Stackebrandt, E. \& Goebel, B. M. (1994). Taxonomic note: a place for DNA-DNA reassociation and $16 \mathrm{~S}$ rRNA sequence analysis in the present species definition in bacteriology. Int J Syst Bacteriol 44, 846-849.

Van Landschoot, A. \& De Ley, J. (1983). Intra- and intergeneric similarities of the rRNA cistrons of Alteromonas, Marinomonas (gen. nov.) and some other Gram-negative bacteria. J Gen Microbiol 129, 3057-3074.

Wayne, L. G., Brenner, D. J., Colwell, R. R., Grimont, P. A. D., Kandler, O., Krichevsky, M. I., Moore, L. H., Moore, W. E. C., Murray, R. G. E. \& other authors (1987). International Committee on Systematic Bacteriology. Report of the ad hoc committee on reconciliation of approaches to bacterial systematics. Int J Syst Bacteriol 37, 463-464.

Yoon, J.-H., Kang, S.-J. \& Oh, T.-K. (2005). Marinomonas dokdonensis sp. nov., isolated from sea water. Int J Syst Evol Microbiol 55, 2303-2307.

Zhang, D.-C., Yu, Y., Chen, B., Wang, H.-X., Liu, H.-C., Dong, X.-Z. \& Zhou, P.-J. (2006). Glaciecola psychrophila sp. nov., a novel psychrophilic bacterium isolated from the Arctic. Int J Syst Evol Microbiol 56, 2867-2869. 